\title{
MANAJEMEN PERAWATAN TRUK JENIS MITSUBISHI DENGAN PENDEKATAN METODE REALIBILITY CENTERED MAINTENANCE (RCM) STUDY KASUS DI CV. BAROKAH DJAYA
}

\author{
M. Abas Maarif \\ email: abasmaarif8@gmail.com \\ Teknik Industri, Fakultas Teknik \\ Universitas Maarif Hasyim Latif, Sidoarjo, Indonesia
}

\begin{abstract}
ABSTRAK
Salah satu model transportasi yang dibutuhkan dalam pembangunan ekonomi adalah jasa angkutan. Perusahaan jasa angkut barang menyumbang kontribusi yang cukup signifikan dalam pengembangan industri-industri kecil maupun besar seperti UKM, jual beli online dan e-commerce. Fokus utama pada penelitian ini adalah pada perusahaan perorangan CV. Barokah Djaya yang berdomisili di Desa Kec.Driyorejo - Kab.Gresik. Beberapa permasalahan terjadi pada manajemen perusahaan tersebut, antara lain belum memiliki jadwal preventive maintenance sehingga terjadi kerusakan komponen mesin truk yang tak terduga. Hal ini cukup berpengaruh terhadap kelancaran pengiriman barang, serta pengeluaran biaya perawatan. Penelitian ini bertujuan untuk mengetahui komponen mesin truk apa saja yang sering mengalami kerusakan, interval waktu yang optimal untuk melakukan perawatan komponen mesin, dan menentukan tindakan yang direkomendasikan dalam perawatan mesin truk yang optimal. Metode analisis yang digunakan dengan metode Reliability Centered Maintenance (RCM). Berdasarkan analisis didapatkan bahwa komponen yang sering mengalami kegagalan (failure dan repair) terjadi pada mesin truk tipe Mitsubishi Nopol S 9519 W yaitu pada komponen Compressor dengan mengalami kerusakan mesin sebanyak 5 kali dalam setahun (Januari - Desember 2019). Komponen kritis compressor pada mesin truk tipe Mitsubishi Nopol S 9519 W memiliki interval perawatan optimal sebesar 879.6 jam (37 hari). Rekomendasi tindakan preventive maintenance komponen compressor pada mesin truk yaitu selama 37 hari sekali
\end{abstract}

Kata Kunci: perawatan, mesin truk, Reliability Centered Maintenance (RCM), manajemen.

\section{PENDAHULUAN}

Salah satu model transportasi yang dibutuhkan dalam pembangunan ekonomi adalah jasa angkutan truk. Jasa angkutan truk ini merupakan sebagian dari jasa angkutan (transportasi) yang luas, yang mana didefinisikan sebagai salah satu yang terdiri dari beberapa elemen prasarana fisik (jaringan, terminal, pelabuhan), sarana angkutan, dan sistem operasional yang mendukung sebuah kelancaran perpindahan objek fisik (manusia dan atau barang) dari suatu titik tempat asal ke tempat titik tujuan yang terpisahkan secara geografis (Irwan, 2013). Selain itu, menurut Anton (2018), Perusahaan jasa angkut barang ini, menyumbang kontribusi yang cukup signifikan dalan pengembangan industriindustri kecil maupun besar seperti UKM, jual beli online, dan e-commerce.

(Prasetya \& Ardhyani, 2019) Adapun salah satu perusahaan yang bergerak pada jasa angkutan barang ini adalah perusahaan perorangan, yaitu CV. Barokah Djaya yang berdomisili di Desa Tanjungan RT:12/RW:003 Kec.Driyorejo Kab.Gresik yang berdiri sejak tahun 2010. Awalnya perusahaan ini hanya memiliki 1 unit truk skala kecil yang biasanya disebut dengan nama truk Colt
Diesel. Lambat laun setelah CV. Barokah Djaya memutuskan untuk bekerja sama dengan rekanan, CV. Barokah Djaya pun mulai mempunyai beberapa unit truk dari skala kecil maupun skala besar yang biasanya disebut truk Fuso. Masa keemasan perusahaan jasa ini mulai berkembang pada tahun 2014 di mana perusahaan jasa ini sudah mampu untuk membeli truk sendiri dan bukan truk rekanan lagi. Beberapa perusahaan pesaing CV.Barokah Djaya yang sama-sama bergerak di bidang jasa angkutan barang di antaranya adalah PT. Bhakti Mulya dan CV. Artha Airlangga di Krian, Sidoarjo, serta PT. Aprisa Jaya di Prambon, Sidoarjo.

Adapun truk yang dimiliki CV. Barokah Djaya adalah sbb :

1. Truk Mitsubishi - 11 Unit.

2. Truk Hino - 9 Unit.

3. Truk Nissan -4 Unit.

Berdasarkan uraian diatas, maka penelitian ini akan difokuskan pada perusahaan jasa angkutan barang yang mempunyai potensi untuk berkembang. Dari beberapa perusahaan jasa angkutan barang diatas, yang akan dijadikan fokus utama pada penelitian ini adalah perusahaan perorangan CV. Barokah Djaya. Terlepas dari keberhasilan CV. Barokah Djaya dalam 
mengembangkan perusahaanya, peneliti menemukan beberapa hal masih membutuhkan perbaikan dalam sistem manajemen perusahaan tersebut, antara lain selama ini CV. Barokah Djaya belum memiliki jadwal preventive maintenance sehingga terjadi kerusakan komponen mesin truk yang tak terduga yang berpengaruh besar terhadap pengiriman barang serta biaya perawatan. Manfaat dari penelitian ini diharapkan bisa memberi wawasan baru untuk pembaca, khususnya perusahaan yang bersangkutan maupun perusahaan jasa angkutan barang lainnya agar bisa dijadikan referensi dalam pengembangan bisnis.

\section{METODE PENELITIAN}

Penelitian ini mengimplementasikan metode realibiliy centered maintenance yang mana dalam metode ini mempunyai tahapan - tahapan sebagai berikut:

1. Observasi, dilakukan dengan cara pengamatan langsung terhadap keadaan sebenarnya yang terjadi di dalam perusahaan yang berhubungan erat dengan permasalahan yang diteliti terhadap proses pemeliharaan yang dilakukan pada mesin truk Mitsubishi.

2. Wawancara, pengumpulan data dengan cara interview secara langsung dilakukan untuk menggali informasi dari karyawan terkait data perawatan yang dilakukan perusahaan terhadap mesin truk Mitsubishi CV. Barokah Djaya.

3. Dokumentasi, dalam hal ini, data - data yang perlu didokumentasikan adalah semua data kerusakan pada mesin truk Mitsubishi selama 1 (satu) tahun mulai Januari - Desember 2019.

Berdasarkan data tersebut, akan ditentukan waktu kapan untuk perbaikan dengan cara menentukan MTTR (Mean Time To Repair) dan waktu kapan untuk pergantian dengan menetukan MTTF (Mean Time To Failure). Setelah penentuan MTTR dan MTTF, maka akan menghasilkan waktu reliability pada komponen mesin yang mengalami kerusakan.

Setelah perhitungan pengolahan data, selanjutnya akan dihitung data FMEA (Failure mode And Efect Analysis) yang mana disetiap kerusakan akan dikelompokkan menjadi sebuah kegagalan dan akibat dari kegagalan tersebut. Setelah itu ditentukan nilai RPN (Risk Potential Number) dengan rumus perhitungan Severity $x$ Occurance $x$ Detection, kemudian penentuan data LTA (Logic Tree Analysis) yaitu pengelompokan data kerusakan untuk dikategorikan pada Safety Problem, Outage Problem, Economic Problem, Hidden Failure (Ariyanto, 2017).

\section{HASIL DAN PEMBAHASAN}

\section{Penentuan Mesin Kritis}

Berdasarkan dari data yang dihimpun dari wawancara dengan pimpinan CV. BAROKAH DJAYA, maka didapat hasil mengenai jumlah kerusakan ke-3 mesin truk tersebut dalam kurun waktu satu tahun, adalah sebagai berikut:

Tabel 1 Jumlah total Kerusakan mesin truk selama Januari-Desember 2019

\begin{tabular}{|c|c|c|c|c|c|c|c|c|c|c|c|}
\hline No & $\begin{array}{l}\text { Tipt } \\
\text { Truck }\end{array}$ & $J_{3 x}$ & $\mathrm{~F} e \mathrm{~b}$ & Mar & Apr & Mei & Jw & Jul & Agw & Oktr & $\begin{array}{c}\text { Jumlab } \\
\text { Kerwakase }\end{array}$ \\
\hline 1 & Mitrobiabi & 122 & 25 & 59 & 61 & 92 & 6 & 0 & 0 & 3 & 369 \\
\hline 2 & Hiso & 71 & 31 & 24 & 95 & 98 & 38 & 6 & 3 & 1 & $36 ?$ \\
\hline 3 & Niman & 11 & 16 & 0 & 3 & 16 & 0 & 0 & 0 & 7 & $\$ s$ \\
\hline \multicolumn{11}{|c|}{ Tota! } & 790 \\
\hline
\end{tabular}

Berdasarkan pengelompokan mesin truk di atas, dapat ketahui jumlah kerusakan yang dialami masing-masing jenis mesin truk selama kurun waktu satu tahun mulai Januari-Desember 2019, dimana jenis mesin truk tipe Mitsubishi yang mengalami kerusakan paling banyak yaitu 386 kali/tahun, kemudian diurutan kedua mesin truk tipe Hino dengan kerusakan sebanyak 367 kali/tahun. Untuk lebih jelas dapat dilihat pada gambar diagram berikut ini.

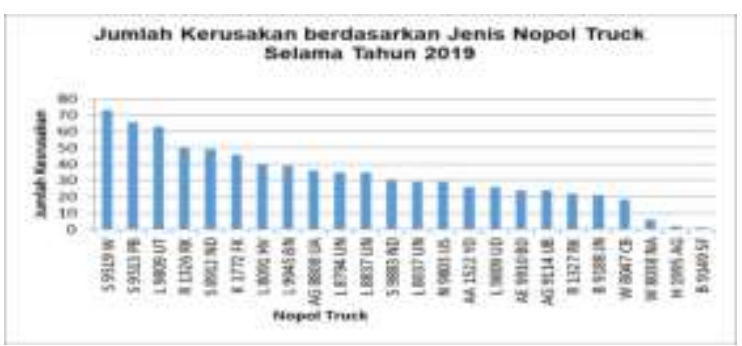

Gambar 1. Jumlah kerusakan mesin selama tahun 2019

Selanjutnya akan dibuat tabel persentase kumulatif yang akan digunakan untuk menggambarkan diagram pareto kerusakan mesin. Berikut ini adalah tabel hasil perhitungan persentase kerusakan kumulatif.

Tabel 2. Persentase Kerusakan Kumulatif Mesin Truk Mitsubishi

\begin{tabular}{|c|l|c|c|c|c|}
\hline No & $\begin{array}{c}\text { Tipe } \\
\text { Truck }\end{array}$ & $\begin{array}{c}\text { Jumlah } \\
\text { Kerusakan }\end{array}$ & Kumulatif & Prosentase & $\begin{array}{c}\text { Prosentae } \\
\text { Kumulatif }\end{array}$ \\
\hline 1 & Mitsubishi & 368 & 368 & $46.6 \%$ & $46.6 \%$ \\
\hline 2 & Hino & 367 & 735 & $46.5 \%$ & $93.0 \%$ \\
\hline 3 & Nissan & 55 & 790 & $7.0 \%$ & $100.0 \%$ \\
\hline \multicolumn{2}{|c|}{ Total } & 790 & & $100.0 \%$ & \\
\hline
\end{tabular}

Berdasarkan tabel 2 di atas maka dapat diketahui bahwa secara kumulatif $20 \%$ mesin truk pada CV. BAROKAH DJAYA mengalami kondisi kritis yaitu pada mesin truk tipe Mitsubishi. Berikut ini adalah gambar diagram pareto dari semua kerusakan mesin truk. 


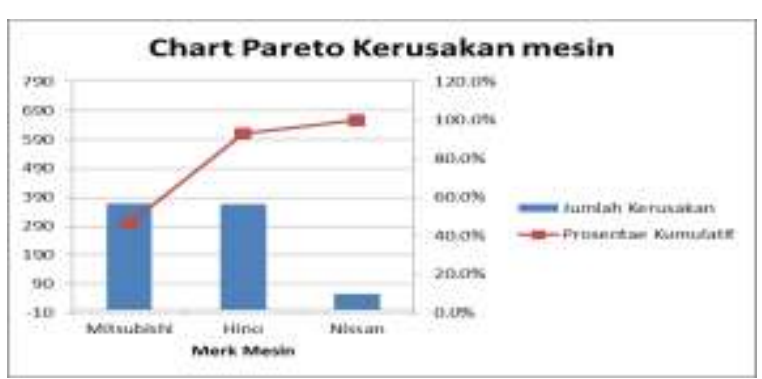

Berdasarkan gambar diagram pareto di atas maka ditentukan jenis mesin truk tipe Mitsubishi dengan nopol S 9519 W yang diambil sebagai objek penelitian, karena mengalami kerusakan mesin yang paling sering terjadi.

\section{Fungsi Sistem dan kegagalan fungsi}

Fungsi sistem dan kegagalan fungsional ditentukan berdasarkan informasi mengenai jenis kegagalan atau kerusakan yang terjadi pada sistem yang diamati. Pada tahap ini penting dilakukan untuk selanjutnya dapat dianalisis dengan FMEA, fungsi sistem dan kegagalan fungsi dapat dilihat pada tabel berikut:

Tabel 3 FMEA fungsi sistem dan kegagalan fungsi

\begin{tabular}{|c|c|c|c|c|c|c|c|c|c|c|c|}
\hline & $x_{t}$ & Кімарев: & Fapp & Kagala & $\begin{array}{l}\text { Fayibat } \\
\text { Veniaka }\end{array}$ & Danpak & 5 & 0 & D & EN & Gir \\
\hline \multirow{7}{*}{ 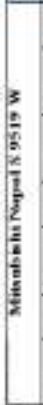 } & 1 & $\begin{array}{l}\text { Bient } \\
\text { afind }\end{array}$ & 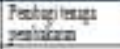 & $\begin{array}{l}\text { Scpows } \\
\text { ingaps }\end{array}$ & Plaver a & $\begin{array}{l}\text { Tauprasos } \\
\text { beturag }\end{array}$ & 1 & ] & 1 & 7 & 7 \\
\hline & 2 & \begin{tabular}{|l} 
Sinno \\
Serites
\end{tabular} & $\begin{array}{l}\text { Praspera bo } \\
\text { moistay. }\end{array}$ & 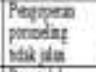 & Sed minas & 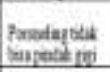 & 1 & 3 & $t$ & 18 & 1 \\
\hline & 3 & Corpante & $\begin{array}{l}\text { Unakeple ap } \\
\text { pahtiv: }\end{array}$ & $\begin{array}{l}\text { Rendil } \\
\text { fappi }\end{array}$ & 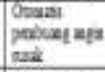 & 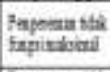 & 9 & 6 & 1 & 31 & 1 \\
\hline & 4 & $\sin 0 \operatorname{se}=$ & 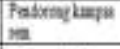 & Partikat & 3tad ande & 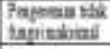 & 10 & 4 & $t$ & 246 & 2 \\
\hline & 1 & Ioa & 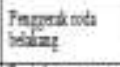 & 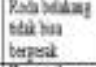 & Sceanithd & $\begin{array}{l}\text { Mencher } \\
\text { betant }\end{array}$ & 8 & 2 & 6 & th & 0 \\
\hline & 1 & 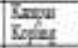 & 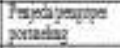 & Kayph hasu & 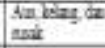 & 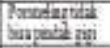 & 8 & 5 & 4 & 20 & $i$ \\
\hline & 1 & Berny & 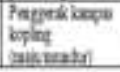 & $\begin{array}{l}\text { Gridiat } \\
\text { bame }\end{array}$ & 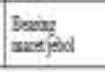 & $\begin{array}{l}\text { Koping tat } \\
\text { betage }\end{array}$ & - & 5 & 4 & 裹 & 3 \\
\hline
\end{tabular}

Berdasarkan tabel 3 diatas maka didapat nilai SOD ( severity, occurrence, detection) dan nilai Risk Priority Number (RPN) dari masing-masing komponen. Dimana nilai komponen secara pareto yang sering mengalami kegagalan yaitu Compressor dengan nilai 378 kali perbaikan.

\section{Komponen Kritis}

Analisis komponen kritis didasarkan dari rangking jumlah RPN di tabel FMEA sebelumnya. Hasil perhitungan RPN yang didapat dari perkalian severity, occurance, dan detection. Setelah didapat rangking perhitungan RPN, langkah selanjutnya akan ditentukan prioritas mode kegagalan dengan menggunakan metode ABC untuk melakukan perbaikan. Berikut hasil rekap RPN dari analisa FMEA:
Tabel 4 Rekap RPN analisa FMEA

\begin{tabular}{|c|c|c|c|c|c|c|c|c|c|}
\hline No. & $\begin{array}{l}\text { Koupones: } \\
\text { Equipueat }\end{array}$ & s & 0 & D & RPN & Real: & Presentase & Kunglatif\% & Grade \\
\hline 1 & Compresser & 9 & 6 & 7 & 378 & I & $29.8 \%$ & $298 \%$ & A \\
\hline 2 & Servoran & 10 & 4 & 6 & 240 & 2 & $18.9 \%$ & $48.8 \%$ & $B$ \\
\hline 3 & Bearing & 3 & 6 & 4 & 192 & 3 & $15.2 \%$ & $639 \%$ & $B$ \\
\hline 4 & Kampas koping & 3 & 5 & 4 & 160 & 4 & $12.6 \%$ & 76.64 & $B$ \\
\hline 5 & Servolkgling & 7 & 3 & 6 & 126 & 5 & $9.9 \%$ & $865 \%$ & $c$ \\
\hline 6 & Joen & 3 & 2 & 6 & 96 & 6 & $7.6 \%$ & 94.116 & $c$ \\
\hline \multirow[t]{2}{*}{7} & Haed cylinter & 5 & 3 & 5 & 75 & 7 & $5.9 \%$ & $1000 \%$ & $c$ \\
\hline & & & & & 1267 & & $100 . \mathrm{N \%}$ & & \\
\hline
\end{tabular}

Berdasarkan tabel 4 di atas, hasil metode ABC didapatkan 1 komponen grade $\mathrm{A}$ dengan presentase kumulatif sebesar kurang dari 40\% yang dianggap sebagai komponen kritis dari keseluruhan total jumlah RPN komponen mesin. Komponen-komponen tersebut akan dilakukan analisa lebih mendalam. Adapun komponen tersebut yaitu: Compressor.

\section{Waktu Kerusakan dan Perbaikan}

Data kerusakan terdiri dari tanggal dan jam terjadinya kerusakan dan perbaikan, yang mana berupa waktu downtime yang digunakan untuk menentukan parameter distribusi waktu time to repair (TTR) dan time to failure (TTR). Perhitungan time to repair ini memperhitungkan jumlah waktu ketika komponen mesin truk rusak hingga komponen selesai diperbaiki. Perhitungan time to failure memperhitungakan jumlah waktu ketika komponen mesin truk selesai diperbaiki hingga komponen rusak kembali.

Tabel 5 Downtime 1 tahun

\begin{tabular}{|l|c|c|r|r|r|r|}
\hline \multicolumn{2}{|c|}{ Mulai } & \multicolumn{1}{c|}{ Selesai } & \multicolumn{2}{c|}{ Downtime } & TTR & TTF \\
\hline Bulan & Tanggal \& Waktu & Tanggal \& Waktu & menit & (Jam:Menit) & Jam & Jam \\
\hline Maret & $3 / 26 / 201910: 20$ & $3 / 26 / 201911: 00$ & 40 & $0: 40: 00$ & 0.67 & 0 \\
\hline Maret & $3 / 30 / 201913: 30$ & $3 / 30 / 201914: 00$ & 30 & $0: 30: 00$ & 0.50 & 98.50 \\
\hline April & $4 / 5 / 20199: 00$ & $4 / 5 / 201910: 00$ & 60 & $1: 00: 00$ & 1.00 & 139.00 \\
\hline Mei & $5 / 13 / 201913: 00$ & $5 / 13 / 201915: 30$ & 150 & $2: 30: 00$ & 2.50 & 915.00 \\
\hline Juni & $6 / 16 / 201913: 00$ & $6 / 16 / 201914: 30$ & 90 & $1: 30: 00$ & 1.50 & 813.50 \\
\hline
\end{tabular}

Berdasarkan tabel 5 diatas, diperoleh hasil downtime selama 1 tahun terakhir dimana digunakan sebagai acuan penghitungan distribusi time to repair dan time to failure.

\section{Perhitungan Total Biaya Perawatan Optimal}

Setelah melakukan perhitungan MTTF dan MTTR, maka langkah selanjutnya adalah melakukan perhitungan total biaya perawatan optimal. Total biaya perawatan optimum didapat dari total biaya perawatan terkecil dari masingmasing komponen kritis mesin truk ekspedisi. 
Pada tahap perhitungan total biaya perawatan yang optimal sekaligus dapat menentukan interval waktu perawatan yang optimum dengan total biaya perawatan terkecil guna untuk dasar pemilihan interval waktu perawatan secara optimal, adapun perhitungan interval perawatan sebagai berikut :

$$
\begin{aligned}
& \mathrm{Cf}=\mathrm{Cr}+\mathrm{Tf}(\mathrm{Co}+\mathrm{Cw}) \\
& \mathrm{TM}=\theta\left(\frac{\mathrm{cm}}{(c f-c m)} \times \frac{1}{\beta-1}\right)^{\frac{2}{\beta}}
\end{aligned}
$$

Keterangan :

Cf = Biaya perbaikan karena kerusakan komponen setiap siklus perawatan

$\mathrm{Cr}=$ Biaya pergantian kerusakan komponen

Co = Biaya kerugian produksi

$\mathrm{Cw}=$ Biaya tenaga kerja

$\mathrm{TM}=$ Interval perawatan

$\mathrm{CM}=$ Biaya yang dikeluarkan untuk perawatan

\section{Biaya tenaga kerja (Cw)}

Biaya tenaga kerja meliputi biaya tukang servis dan biaya pergantian, dapat dilihat pada tabel berikut:

\section{Tabel 6 Biaya Servis}

\begin{tabular}{|l|l|c|c|c|}
\hline & Parts Changing & Qty & $\begin{array}{c}\text { Harga } \\
\text { Spare } \\
\text { Parts }\end{array}$ & $\begin{array}{c}\text { Jasa } \\
\text { Repairing/services }\end{array}$ \\
\hline \multirow{4}{*}{$\begin{array}{l}\text { Service } \\
\text { Compressor }\end{array}$} & Klem selang 1/4" & 2 pcs & 7,000 & 200,000 \\
\cline { 2 - 5 } & Selangplastic & $4 \mathrm{mtr}$ & 36,000 & 200,000 \\
\cline { 2 - 5 } & Klem selang 3/4" & $2 \mathrm{pcs}$ & 3,000 & 200,000 \\
\cline { 2 - 5 } & Selang 3/4 x 2B & $0.5 \mathrm{mtr}$ & 10,000 & 200,000 \\
\cline { 2 - 5 } & Selangplastic & $4 \mathrm{mtr}$ & 36,000 & 200,000 \\
\hline \multicolumn{6}{|c|}{ Total Biaya Cw } & $1,000,000$ \\
\hline
\end{tabular}

Berdasarkan tabel 6 diatas, maka dapat diketahui berapa besar biaya jasa perbaikan yang harus dikeluarkan perusahaan untuk service Compressor sebesar Rp 1.000.000,- per unit nya.

\section{Biaya Pergantian komponen (Cr)}

Biaya ini muncul akibat adanya kerusakan yang menimbulkan pergantian pada sub komponen (spare part) compressor. Biaya pergantian spare part compressor dapat dilihat pada rincian tabel berikut:

Tabel 7 Biaya pergantian

\begin{tabular}{|l|l|c|c|}
\hline & \multicolumn{1}{|c|}{ Parts Changing } & Qty & Harga Spare Parts \\
\hline \multirow{4}{*}{$\begin{array}{l}\text { Service } \\
\text { Compressor }\end{array}$} & Klem selang 1/4" & $2 \mathrm{pcs}$ & 7,000 \\
\cline { 2 - 4 } & Selangplastic & $4 \mathrm{mtr}$ & 36,000 \\
\cline { 2 - 4 } & Klem selang 3/4" & $2 \mathrm{pcs}$ & 3,000 \\
\cline { 2 - 4 } & Selang 3/4 x 2B & $0.5 \mathrm{mtr}$ & 10,000 \\
\cline { 2 - 4 } & Selangplastic & $4 \mathrm{mtr}$ & 36,000 \\
\hline \multicolumn{2}{|l}{ Total Biaya Cr } & & 92,000 \\
\hline
\end{tabular}

Dari Tabel 7 diatas, dapat diketahui sparepart yang dibutuhkan untuk pergantian komponen yang rusak dan total biaya pergantian komponen sebesar Rp 92.000.00,- per unit Compressor.

\section{Biaya Kerugian Pendapatan (Co)}

Biaya kerugian produksi diperoleh dari keuntungan yang hilang akibat kerusakan /perawatan mesin yang mengakibatkan mesin berhenti beroperasi. Mesin truk mampu melayani berbagai macam angkutan dan menghasilkan keuntungan 1 rit/hari sebesar Rp. 1.500.000,- bagi perusahaan. Sehingga dapat dihitung besarnya keuntungan perjam $=\operatorname{Rp} 1.500 .000 / 24=\mathrm{Rp}$. $62.500,-$.

CV Barokah Djaya mengalami hilangnya keuntungan (opportunity cost) dari pelayanan jasa angkutan akibat mesin truk berhenti tidak dapat beroperasi, yaitu mengalami kerugian per jamnya adalah: Rp. 62.500,--

\section{Biaya Perawatan (Cm)}

Biaya untuk perawatan adalah biaya yang ditimbulkan karena adanya perawatan. Biaya untuk perawatan meliputi biaya tenaga kerja, biaya downtime (biaya downtime ditetapkan perusahaan sebesasr $20 \%$ dari biaya kerugian produksi) dan biaya material. Biaya perawatan dihitung dengan rumus sebagai berikut:

$\mathrm{Cm}=(($ biaya kerugian + biaya downtime $) \mathrm{Tp})+$ biaya material + biaya tenaga servis

Tabel 8 Hasil perhitungan biaya untuk perawatan

\begin{tabular}{|l|c|c|c|c|c|c|}
\hline \multirow{2}{*}{ Komponen } & $\begin{array}{c}\text { Biaya } \\
\text { Kerugian }\end{array}$ & Downtime & $\mathrm{Tp}$ & $\begin{array}{c}\text { Biaya } \\
\text { Tenaga } \\
\text { Servis }\end{array}$ & $\begin{array}{c}\text { Biaya } \\
\text { Material }\end{array}$ & $\mathrm{CM}$ \\
\cline { 2 - 7 } & (Rupiah) & (Rupiah) & (Jam) & (Rupiah) & (Rupiah) & Rupiah \\
\hline $\begin{array}{l}\text { Compressor } \\
\begin{array}{l}\text { Mesin Truk } \\
\text { Mitsubishi } \\
\text { Nopol S } \\
\text { 9519 W }\end{array}\end{array}$ & 62,500 & 12,500 & 1.00 & $1,000,000$ & 92,000 & $1,167,000$ \\
\hline
\end{tabular}

Tabel 8 diatas menerangkan bahwa cost perawatan Compressor mesin truk Mitsubishi memiliki biaya sebesar $\operatorname{Rp} 1,167,000$,- dengan ketentuan waktu perawatan (Tp) sebesar 1 jam. Preventive Cost adalah biaya yang ditimbulkan karena adanya perawatan yang sudah dijadwalkan. Sedangkan Failure Cost, itu merupakan biaya yang ada karena kerusakan di luar penjadwalan yang menyebabkan mesin truk berhenti.

\section{Biaya perbaikan kerusakan setiap siklus perawatan (Cf)}

Biaya perbaikan akibat kerusakan komponen setiap siklus perawatan adalah biaya yang timbul akibat adanya kerusakan komponen mesin. Biaya ini meliputi biaya kerugian produksi, biaya tenaga kerja dan biaya material. Biaya perawatan dihitung dengan rumus sebagai berikut $\mathrm{Cf}=(($ biaya kerugian + biaya downtime $) \mathrm{Tf})+$ biaya material + biaya tenaga servis 
Tabel 9 Hasil rekap perhitungan biaya perbaikan akibat kerusakan

\begin{tabular}{|c|c|c|c|c|c|c|}
\hline \multirow[t]{2}{*}{ Komponen } & $\begin{array}{c}\text { Biaya } \\
\text { Kerugia } \\
n\end{array}$ & Downtim & $\mathrm{Tr}$ & $\begin{array}{l}\text { Biaya } \\
\text { Tenaga } \\
\text { Servis }\end{array}$ & $\begin{array}{c}\text { Biaya } \\
\text { Material }\end{array}$ & $\mathrm{Cr}$ \\
\hline & (Rupiah) & (Rupiah) & Jam & (Rupiah) & (Rupiah & Rupiah \\
\hline $\begin{array}{l}\text { Compreaisor } \\
\text { Menin Truk } \\
\text { Mitsubishi } \\
\text { Nopols } 9519 \\
\text { W }\end{array}$ & 62,300 & 12,500 & 1,24 & $1,000,00$ & 92,000 & $1,185,00$ \\
\hline
\end{tabular}

Berdasarkan tabel 9 diatas, bahwa biaya perbaikan komponen Compressor mesin truk Mitsubishi Nopol S 9519 W sebesar Rp 1,185,000,- dengan nilai Tf sebesar 1,24 jam.

Perhitungan Interval Perawatan Optimal (TM) Perhitungan interval perawatan optimal menggunakan rumus:

$$
\begin{aligned}
& \mathrm{TM}=\theta\left(\frac{C m}{(C f-C m)} \cdot \frac{1}{(\beta-1)}\right)^{\frac{1}{\beta}}
\end{aligned}
$$

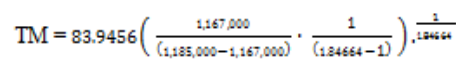

$$
\begin{aligned}
& \mathrm{TM}=879.60
\end{aligned}
$$

Tabel 10 Hasil rekap perhitungan interval perawatan optimal

\begin{tabular}{|c|c|c|c|c|c|c|c|}
\hline Mesa Krotis & Korrposen & Shayse & Scale $\theta$ & $\begin{array}{c}\mathrm{CU} \\
\text { (Panpih) }\end{array}$ & $\begin{array}{c}C g \\
\text { (Ruriak) }\end{array}$ & $\begin{array}{l}\text { TM } \\
(\mathrm{gm})\end{array}$ & Har \\
\hline & upresset & 1.84664 & 39456 & $1,167,050$ & $1,185,000$ & 879.60 & \\
\hline
\end{tabular}

Berdasarkan table 10 menunjukan bahwa komponen Compressor mesin truk Mitsubishi Nopol S 9519 W memiliki interval perawatan optimal sebesar 879.60 jam atau 37 hari. Perhitungan total biaya selama perawatan sebelum dan sesudah adanya program perawatan terencana dalam 1 periode. Dari perhitungan interval waktu perawatan, maka langkah selanjutnya mencari total biaya perawatan dalam masa 1 periode. Perhitungan 1 Periode $=(8$ jam $\times 6$ hari $)+(5$ jam $\mathrm{x}$ 1 hari) $\times 52$ minggu $=2756$ jam.

\section{Biaya Sebelum Perawatan Terencana (TP)}

Biaya sebelum adanya perawatan terencana (TP) komponen mesin dapat dihitung menggunakan rumus sebagai berikut:

$\mathrm{TP}=$ Biaya Kerusakan $(\mathrm{Cf}) \mathrm{x}$ Banyaknya

Kerusakan

Dimana,

Biaya Kerusakan (Cf)

Banyaknya kerusakan (N)

$=$ Rp. $1,185,000$

$=\frac{t}{M T T F}=\frac{2756}{561.17}$

$=4.911168$

Jadi,

$$
\begin{aligned}
\mathrm{TP} & =\text { Rp. } 1,185,000 \times 4.911168 \\
& =\text { Rp. } 5819734
\end{aligned}
$$

\section{Total Biaya Perawatan Optimum (TC)}

Berikut adalah langkah-langkah dan perhitungan TC komponen Compressor mesin truk Mitsubishi Nopol S 9519 W, yaitu menghitung
Probabilitas Rusak dan Probabilitas Baik dengan menggunakan rumus sebagai berikut:

1. Perhitungan Probabilitas Rusak (P (TTF $\leq \mathrm{TM})$ ) Rumus perhitungan probabalitas rusak pada komponen compressor, sebagai berikut:

$$
\begin{aligned}
\mathrm{P}(\mathrm{TTF} \leq \mathrm{TM}) & =\int_{\infty}^{T M} f(t) d t \\
& =\int_{\infty}^{T M \alpha} \frac{\alpha}{\beta}\left(\left(\frac{t}{\beta}\right)^{\alpha-1} \exp \left[-\left(\frac{t}{\beta}\right)^{\alpha}\right] \mathrm{dt}\right.
\end{aligned}
$$

2. Perhitungan Probabilitas Baik P (TTF $>$ TM) Rumus perhitungan probabalitas baik pada komponen compressor, sebagai berikut:

$$
\begin{aligned}
\mathrm{P}(\mathrm{TTF}>\mathrm{TM}) & =\int_{T M}^{\infty} f(t) d t \\
& =\int_{T M}^{\infty} \frac{\alpha}{\beta}\left(\left(\frac{\mathrm{t}}{\beta}\right)^{\alpha-1} \exp \left[-\left(\frac{\mathrm{t}}{\beta}\right)^{\alpha}\right] \mathrm{dt}\right. \\
& =1-\mathrm{P}(\mathrm{TTF} \leq \mathrm{TM})
\end{aligned}
$$

3. Perhitungan TC

Rumus perhitungan TC optimal pada komponen compressor mesin truk Mitsubishi Nopol S $9519 \mathrm{~W}$ adalah sebagai berikut:

$\mathrm{TC}=(\mathrm{P}(\mathrm{TTF} \leq \mathrm{TM}) \mathrm{Cf})+(\mathrm{P}(\mathrm{TTF}>\mathrm{TM}) \mathrm{Cm}) \mathrm{x}$ Jam Kerja Siklus

Selanjutnya akan dihitung terlebih dahulu

\begin{tabular}{|c|c|c|c|c|c|c|c|c|}
\hline I & ti & $\mathbf{X} \mathrm{I}$ & RMI & $F(t)$ & 도 & sid & sin't & $\operatorname{tin} 2$ \\
\hline 1 & 105.00 & 5.1059 & 0.1591 & 0.1733 & -1.7529 & -89502 & 250007 & 3,0726 \\
\hline 2 & 81250 & 6.7013 & 0.3564 & 0.4854 & -0.7167 & 43050 & 49090 & $05: 37$ \\
\hline 3 & 912.33 & 0.8160 & 0.6136 & 0.9510 & -0.0503 & -0.3426 & 46.4579 & 0,0025 \\
\hline 4 & 91500 & 6.8159 & 0.8409 & 1.8387 & 0.6058 & 41516 & 45.4977 & $0.310 ?$ \\
\hline Jemilsh & 2805.33 & 25.4622 & 2.0000 & 3.4509 & 19110 & 99442 & 1639344 & $3 \frac{3955}{19}$ \\
\hline $\begin{array}{l}\text { Rets } \\
\text { anta }\end{array}$ & 701.4583 & 8.3606 & 0.50000 & 0.3627 & 0.4778 & 2.4361 & 4) 9836 & 0,9899 \\
\hline
\end{tabular}
parameter-parameter yang dibutuhkan dalam perhitungan TC yaitu parameter $\alpha$ dan $\beta$, adapun menghitung parameter $\alpha$ dan $\beta$ dilakukan menggunakan rumus sebagai berikut:

$$
\begin{aligned}
& \mathrm{A}-\bar{\gamma}-\mathrm{b} \bar{X} \\
& \mathrm{~b}-\frac{n \sum_{t=1}^{n} x t y t-\left(\sum_{i=1}^{n}, x t\right)\left(\sum_{i=1}^{n} y t\right)}{n \sum_{i-1}^{n} x t^{2}-\left(\sum_{i-1}^{n} x t\right)^{2}} \\
& \alpha-\mathrm{b} \\
& \beta-\sigma-\left(\frac{n}{b}\right)
\end{aligned}
$$

Tabel 11 perhitungan nilai parameter $\alpha$ dan $\beta$ adalah sebagai berikut :

Berdasarkan hasil perhitungan di atas, maka akan dihitung nilai gradien $\mathrm{b}$ dan konstanta $\mathrm{a}$.

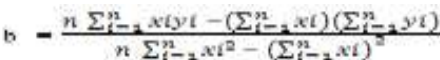

$$
\begin{aligned}
& =\frac{(4)(-9.9147)-(75.1427)(-1.9110)}{4(163.9344)(25.4422)^{2}} \\
& -1.0491 \\
& \text { a }-Y-b: x \\
& --0.4778-(1.0491 \times 6.3606) \\
& -.7 .1504 \\
& \alpha-b \\
& -1.0491 \\
& \text { p }=e^{-\left(\frac{-0}{v}\right)}
\end{aligned}
$$

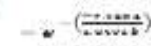

$$
\begin{aligned}
& -912.3055
\end{aligned}
$$




\section{Perhitungan TC Optimal}

Setelah parameter $\alpha$ dan $\beta$ diketahui maka selanjutnya akan menghitung TC optimal sebagai berikut:

diketahui nilai $\alpha=1.0491$ dan $\beta=912.3055$.

1. Perhitungan Probabilitas Rusak (P (TTF $\leq \mathrm{TM})$ )

$$
\begin{aligned}
& \mathrm{P}(\mathrm{TTF} \leq \mathrm{TM}) \quad-\int_{m} f(t) d t \\
& -\int_{\infty}^{T N \alpha} \frac{\alpha}{\sigma}\left(\frac{\tau}{\sigma}\right)^{\mu-1}{ }_{\exp }\left[-\left(\frac{t}{\sigma}\right)^{\prime \prime}\right] \mathrm{dt}
\end{aligned}
$$

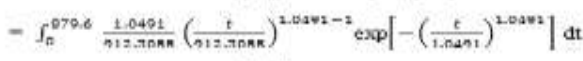

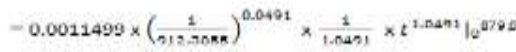

$$
\begin{aligned}
& -0.0624
\end{aligned}
$$

2. Perhitungan Probabilitas Baik $\mathrm{P}(\mathrm{TTF}>\mathrm{TM})$

$$
\begin{aligned}
& \mathrm{P}(\mathrm{TTF}>\mathrm{TM}) \quad-\int_{T M}^{\infty} f(t) d t \\
& -\int_{T N U}^{\infty}-\frac{\omega}{\beta}\left(\left(\frac{t}{\beta}\right)^{a-1}{ }_{\exp }\left[-\left(\frac{t}{\beta}\right)^{\alpha}\right] d t\right. \\
& -1-\mathrm{P}(\mathrm{TTF} \leq \mathrm{TM}) \\
& -1-0.9624 \\
& =0.0376
\end{aligned}
$$

\begin{tabular}{|c|c|c|c|c|c|c|}
\hline & A & $\beta$ & $\begin{array}{c}\mathrm{Tm} \\
\text { (Jam) }\end{array}$ & $\begin{array}{c}\mathrm{Cf} \\
(\mathrm{Rp})\end{array}$ & $\begin{array}{l}\mathrm{Cm} \\
(\mathrm{Rp})\end{array}$ & $\begin{array}{l}T C_{0 y t} \\
(\mathrm{Ro})\end{array}$ \\
\hline $\begin{array}{l}\text { Compressor Mesin } \\
\text { Trik Mitsubishi } \\
\text { Nopdis } 9519 \text { w }\end{array}$ & 10491 & 9123655 & 8796 & $1,185,000$ & $1,167,000$ & $1,27: 865: 14$ \\
\hline
\end{tabular}

3. Perhitungan TC

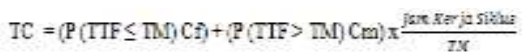

$$
\begin{aligned}
& =(0.9624 \times 1,185,005)-(0.0376 \times 1,167,000) \times \frac{2756}{8756} \\
& =1.277 .865 .14
\end{aligned}
$$

Berdasarkan hasil perhitungan di atas maka dapat dibuat

Tabel 12 Rekapitulasi hasil perhitungan TC optimal

\section{Perhitungan TC Perusahaan}

Perhitungan TC perusahaan pada komponen Compressor mesin truk Mitsubishi Nopol S 9519 W, dilakukan dengan menggunakan rumus sebagai berikut:

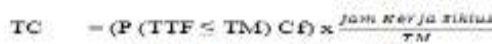

$$
\begin{aligned}
& -(0.2624 \times 1,185,000) \times \frac{27 m a}{8728} \\
& -3,712,592.22
\end{aligned}
$$

Tabel 13 Hasil rekapitulasi perhitungan TC

\begin{tabular}{|c|c|c|c|c|}
\hline & $\begin{array}{l}\text { TC optimnI } \\
\text { (Rp) }\end{array}$ & $\begin{array}{l}\text { TC Perusabaan } \\
(\mathbb{R} p)\end{array}$ & $\begin{array}{c}\text { Peaurussn Bizy3 } \\
\text { (Rp) }\end{array}$ & $\begin{array}{c}\text { Perseatase } \\
\text { (36) }\end{array}$ \\
\hline 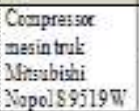 & $1,277,865.14$ & $3,712,89222$ & $2,435,027.08$ & 65.696 \\
\hline
\end{tabular}
perusahaan pada komponen mesin truk yang kritis.

\begin{tabular}{|l|c|c|}
\hline Komponen Mesin Kritis & $\begin{array}{c}\mathbf{T C}_{\text {Optimal }} \\
\text { (Rp) }\end{array}$ & $\begin{array}{c}\text { TC }_{\text {Perusabaan }} \\
\text { (Rp) }\end{array}$ \\
\hline $\begin{array}{l}\text { Compressormesin truk } \\
\text { MitsubishiNopol S 9519 W }\end{array}$ & $1,277,865.14$ & $3,712,892.22$ \\
\hline
\end{tabular}

\section{Penurunan Total Biaya Perawatan}

Berdasarkan hasil perhitngan TC optimal dan TC perusahaan di atas maka dapat dihitung penurunan hasil total biaya perawatan dengan mencari selisih antara nilai TC optimal dan TC perusahaan seperti pada berikut ini:
Tabel 14 Total biaya perawatan dengan mencari selisih antara nilai TC optimal dan TC

Berdasarkan tabel diatas diketahui bahwa hasil perhitungan TC perusahaan lebih besar dari TC optimal dengan selisih sebesar Rp 2.435.027.08. hal ini dapat dikatakan hasil analisis perhitungan total biaya perwatan komponen mesin truk mitsubishi nopol S 9519 W yang kritis mengalami penurunan biaya yaitu sebesar Rp. 2.435.027.08,dengan persentase penurunan sebesar $65,6 \%$.

\section{PENUTUP}

Berdasarkan hasil analisa yang telah dilakukan maka dapat ditarik kesimpulan yaitu :

1. Komponen mesin truk kritis yang sering mengalami kegagalan (failure dan repair) terjadi pada truk tipe Mitsubishi Nopol S 9519 W yaitu pada komponen Compressor dengan mengalami kerusakan sebanyak 5 kali dalam setahun (periode Januari - Desember 2019).

2. Komponen kritis Compressor pada mesin truk tipe Mitsubishi Nopol S 9519 W memiliki interval perawatan optimal sebesar 879.6 jam (37 hari).

3. Melakukan penjadwalan berkala merupakan preventive maintenance yang efektif guna meningkatkkan kehandalan mesin truk dan mencegah terjadinya kejadian yang diluar kendali. Dan merekomendasikan tindakan preventive maintenance komponen mesin truk pada Compressor yaitu selama 37 hari sekali.

\section{DAFTAR PUSTAKA}

Chrisbiyanto, A. (2018). Perusahaan Ekspedisi Berperan Penting Dorong Pertumbuhan UKM. Retrievedfromhttps://ekbis.sindonews.com/re ad/1317290/34/perusahaan-ekspedisi berperan-penting-dorong-pertumbuhan-ukm1530201209

Irwan, A. (2013). Peranan Jasa Angkutan Truk dalam Perekonomian Indonesia. Retrieved fromhttp://transsulawesia.blogspot.com/2013 /02/peranan-jasa-angkutan-truk dalam.html

Prasetya, D., \& Ardhyani, I. W. (2019). Perencanaan Pemeliharaan Mesin Produksi Dengan Menggunakan Metode Reliability Centered Maintenance (RCM)(Studi Kasus: PT. S). JISO: Journal of Industrial and Systems Optimization, 1(1), 7-14. 